Number 3

\title{
HUBUNGAN INDEKS MASSA TUBUH DENGAN KADAR TRIGLISERIDA PADA PENENUN DI DESA TENGANAN KARANGASEM
}

\author{
I Nyoman Krisna Wicaksana ${ }^{1}$, I.G.A. Sri Dhyanaputri², I Nyoman Jirna ${ }^{3}$ \\ 1,2,3 Jurusan Analis Kesehatan Denpasar
}

\begin{abstract}
:
Background Body mass index is the one of the marker of nutritional status related to obesity. Obesity is a multifactorial disease that can lead to an increase in triglycerides. This situation is one of the causes of cardiovascular disease. Objective This study aims to determine the relationship between body mass index in the levels of trigliycerides in weavers in Tenganan Village Karangasem. Methods Designed as study correlation study. The study was done to 26 respondents that were chosen by saturated sampling method. Data of body mass index were measured by anthropometric measurements and data of triglycerides level measured by using a dialab autolyser. The Results showed that 50,00\% participants got obesity and 42,31\% participants had increased triglycerides level, which six participants (23,08\%) got a high limit and five participants $(19,23 \%)$ in the high category. Based on the product moment test, a score is significant correlation between body mass index with triglycerides $(p: 0,000)<(\alpha: 0,05)$. It was Concluded there is a relationship between body mass index with triglycerides level of weavers at Tenganan Village Karangasem.

Keywords: body mass index, obesity, triglycerides
\end{abstract}

\section{PENDAHULUAN}

Penyakit Tidak Menular (PTM) merupakan penyakit kronis yang tidak ditularkan dari orang ke orang. Angka kematian akibat PTM di Indonesia selalu mengalami peningkatan, salah satu penyumbang tertinggi adalah penyakit kardiovaskuler ${ }^{1}$. Salah satu faktor penyebab penyakit kardiovaskuler adalah dislipidemia, merupakan suatu kelaian yang dijumpai pada peningkatan kadar kolestrol, LDL, trigliserida dan penurunan kadar $\mathrm{HDL}^{2}$, kelebihan asupan energi umumnya akan disimpan sebagai trigliserida di jaringan adiposa sehingga menyebabkan timbulnya obesitas ${ }^{3}$.

Prevalensi obesitas selalu mengalami peningkatan di Indonesia dan provinsi Bali termasuk kedalam prevalensi obesitas diatas nasional ${ }^{4,1}$. Status gizi penduduk dewasa yang obesitas di kabupaten Karangasem telah mengalami peningkatan dari 6,3 (2007) menjadi 10,4 (2013) ${ }^{1}$. Keadaan obesitas dapat ditentukan dengan mengklasifikasikan status gizi berdasarkan Indeks Massa Tubuh (IMT) ${ }^{2}$. Kurangnya aktifitas fisik yang dilakukan oleh penenun di desa Tenganan, kabupaten Karangasem dapat menimbulkan penimbunan lemak yang berdampak pada munculnya kelebihan berat badan. Tujuan penelitian adalah untuk mengetahui hubungan indeks massa tubuh dengan kadar trigliserida pada penenun di desa Tenganan Karangasem.

\section{METODE}

Meditory | ISSN Online : 2549-1520, ISSN Cetak : 2338 - 1159, Vol. 7, No. 1, Juni 2019 
Jenis penelitian yang digunakan termasuk penelitian studi korelasi yang dilakukan untuk melihat suatu hubungan variabel dengan variabel yang lain dengan mengidentifikasikan variabel yang ada pada suatu objek ${ }^{5}$. Jenis data yang dikumpulkan adalah data primer yang diperoleh secara langsung oleh peneliti meliputi usia, jenis kelamin, hasil pemeriksaan trigliserida dan IMT yang diperoleh dengan observasi, wawancara dan pemeriksaan laboratorium. Populasi penelitian ini adalah seluruh penenun aktif yang berjumah 26 orang. Sampel penelitian diperoleh dengan menggunakan metode non-probability sampling yaitu sampling jenuh.

Pengumpulan data dilakukan dengan observasi, wawancara dan pemeriksaan kadar trigliserida dengan metode GPOPAP enzymatic colorimetric method dan pengukuran berat badan dengan alat timbangan dan tinggi badan dengan alat antropometer. Data ini dianalisis dengan uji Korelasi Product Moment dan disajikan dalam bentuk tabel dan narasi.

\section{HASIL DAN PEMBAHASAN}

Hasil perhitungan IMT dan pengukuran trigliserida dari 13 responden dengan IMT normal 76,9\% memiliki kadar trigliserida darah yang normal dan dari 13 responden dengan IMT obesitas sebanyak $38,5 \%$ responden memiliki kadar trigliserida darah dalam tinggi. Lebih lengkapnya data dapat dilihat pada table 1 .

Tabel 1. Distribusi IMT dan Kadar Trigliserida

\begin{tabular}{ccccccc}
\hline IMT & \multicolumn{3}{c}{ Kadar Trigliserida } & \multicolumn{2}{c}{ Total } \\
& Normal & $\begin{array}{c}\text { Batas } \\
\text { Tinggi } \\
\mathrm{n}(\%)\end{array}$ & Tinggi & $\begin{array}{c}\text { Sangat } \\
\text { Tinggi }\end{array}$ & & \\
& $\mathrm{n}(\%)$ & $\mathrm{n}(\%)$ & $\sum$ & $\%$ \\
\hline Kurus & $0(0)$ & $0(0)$ & $0(0)$ & $0(0)$ & 0 & 100 \\
Normal & $10(76,9)$ & $3(23,1)$ & $0(0)$ & $0(0)$ & 13 & 100 \\
Obesitas & $5(38,5)$ & $3(23,1)$ & $5(38,5)$ & $0(0)$ & 13 & 100 \\
\hline TOTAL & $15(57,7)$ & $6(23,1)$ & $5(19,2)$ & $0(0)$ & 26 & 100 \\
\hline
\end{tabular}


Nilai IMT yang terendah adalah $19,28 \mathrm{~kg} / \mathrm{m}^{2}$, IMT tertinggi $40,47 \mathrm{~kg} / \mathrm{m}^{2}$, dengan rata-rata IMT $27,04 \mathrm{~kg} / \mathrm{m}^{2}$. Kadar

trigliserida terendah adalah $68 \mathrm{mg} / \mathrm{dl}$, kadar tertinggi $378 \mathrm{mg} / \mathrm{dl}$, sedangkan ratarata kadar trigliserida adalah $150 \mathrm{mg} / \mathrm{dl}$.

Analisis hubungan antara indeks massa tubuh dengan kadar trigliserida pada penenun di desa Tenganan Karangasem dengan uji product moment diperoleh dengan nilai $\mathrm{p}$ sebesar 0,000. Nilai $\mathrm{p}$ ini kemudian dibandingkan dengan signifikasi $\alpha=0,05$. Nilai $p(0,000)<\alpha(0,05)$ menunjukan signifikasi dan menyatakan terdapat hubungan antara indeks massa tubuh dengan kadar trigliserida pada penenun di desa Tenganan Karangasem. Hal ini sejalan dengan penelitian Putri dan Isti yang menyatakan bahwa penumpukan lemak berlebih yang terjadi pada penderita obesitas mengakibatkan meningkatnya jumlah asam lemak bebas yang dihidrolisis oleh LPL endotel ${ }^{6}$. Free Fatty Acid (FFA) yang dilepaskan karena adanya penimbunan lemak yang berlebihan juga menghambat terjadinya lipogenesis sehingga menghambat klirens serum trigliserida sehingga mengakibatkan peningkatan kadar trigliserida. Data pada penelitian ini mengenai faktor lain yang dapat meningkatkan kadar trigliserida dalam darah diperoleh dengan cara wawancara. Pada sebaran responden berdasarkan riwayat penyakit keluarga, terdapat 3 orang $(11,54 \%)$ yang memiliki riwayat trigliserida tinggi (hipertrigliserida) dalam keluarga dan ketiganya memiliki kadar trigliserida diatas normal, hal ini dapat disebabkan oleh hiperlipidemia herediter yang sifatnya diturunkan dan mempengaruhi sistem tubuh dalam fungsi metabolisme serta membuang lemak ${ }^{7}$, serta terdapat 3 orang $(11,54 \%)$ memiliki riwayat penyakit diabetes mellitus dan hanya 1 responden yang memiliki kadar trigliserida diatas normal. Data konsumsi obat terdapat 4 responden $(15,38 \%)$ yang menkonsumsi pil $\mathrm{KB}$ dan 3 diantaranya memiliki skala IMT > 25 (obesitas) hal ini setara dengan penelitian Sriwahyuni dan Wahyuni (2012) yang menyatakan pemakaian kontrasepsi hormonal akan cenderung terjadi peningkatan berat badan ${ }^{8}$. Tidak terdapat responden yang mempunyai kebiasaan merokok maupun minum-minuman beralkohol. Dari hasil wawancara tersebut hanya diperoleh sebagian kecil responden yang memiliki faktor lain selain obesitas yang dapat meningkatkan kadar trigliserida dalam darah. 


\section{SIMPULAN DAN SARAN}

Pengukuran Indeks Massa Tubuh didapat sebanyak 13 responden $(50,00 \%)$ responden mengalami obesitas dan didapatkan sebanyak 11 responden $(42,31 \%)$ responden memiliki kadar trigliserida yang melebihi batas normal. Hasil analisa ada hubungan antara indeks massa tubuh dengan kadar trigliserida pada penenun di desa Tenganan Karangasem dimana $p(0,000)<\alpha(0,05)$.

Saran bagi responden yang memiliki indeks massa tubuh berlebih (obesitas) dan/atau kadar trigliserida yang tinggi agar mengurangi makanan tinggi lemak dan gorengan dan memperbanyak aktifitas fisik.

\section{DAFTAR PUSTAKA}

1. Kemenkes, 2014, Laporan RISKESDAS 2013 Provinsi Bali, Jakarta: Kementerian Kesehatan.

2. Suharjo, J.B., 2008, Gaya Hidup dan Penyakit Modern, Yogyakarta: Kanisius.

3. Mayes, P. A., 2013, Biokimia $H_{1}$

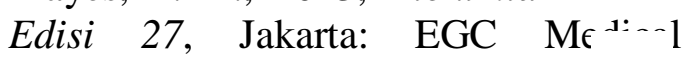
Publisher.

4. Kemenkes, 2010, Laporan RISKESDAS 2010, Jakarta: Kementerian Kesehatan

5. Notoatmodjo, S., 2012, Metodologi Penelitian Kesehatan, Jakarta: PT Rineka Cipta.

6. Putri, S., R., dan Isti, D., A., 2015, Obesitas Sebagai Faktor Resiko
Peningkatan Kadar Trigliserida, Majority, Vol. 4, No. 9: Halaman 78

7. Isselbacher, K. J., et al., 2000, PrinsipPrinsip Ilmu Penyakit Dalam Volume 5, Jakarta: EGC Medical Publisher.

8. Sriwahyuni, E., dan Wahyuni, C., U., 2012, Hubungan antara Jenis dan Lama Pemakaian Alat Kontrasepsi Hormonal dengan Peningkatan Berat Badan Akseptor, The Indonesian Journal of Public Health, Vol. 8, No. 3: Halaman 112

Meditory | ISSN Online : 2549-1520, ISSN Cetak : 2338 - 1159, Vol. 7, No. 1, Juni 2019

HIm. 13 - 16, http://ejournal.poltekkes-denpasar.ac.id/index.php/M 